\title{
Victims or Agents: Self-perception of Dalit Women in Pan on Fire
}

\author{
Pratibha \\ Ph.D Research Scholar, Dept. of English. Jamia Millia Islamia University. ORCID: oooo- \\ ooo1-5698-6612.Email:pratibhabiswas85@gmail.com.
}

\begin{abstract}
The autobiographical narratives by Dalit authors did challenge the 'discourse of pity' by non-Dalit writers, by transforming the recollection of what Cornel West has called "ontological wounding" of the self marked by constant humiliation (Geetha, 2009, p.93), into representation of Dalit subalternity as a political act of resistance. Yet within the narratives of cultural revolt of 1970 s by Dalit Panthers, Dalit women remain encapsulated in the role of either 'the mother' or 'the victimized sexual being', as pointed out by Sharmila Rege (2014, p. 336). Thus, she calls for re-conceptualization of critique of brahmanical hierarchies from a Dalit feminist standpoint. A collection of narrated stories by urban slum-dwelling Dalit women, namely, Rukmini, Chhaya, Rakhma, Sangeeta, Mangala, Ashoka, Savitri and Leela -Pan on Fire: Eight Dalit Women Tell Their Story (1988), provides an incisive account of the Dalit life-world and views on issues like Dalit family organization, culture of poverty, childhood, puberty as experienced by Dalit women and their role in the community glimpsed through relationships with family members. As they recollect and re-evaluate the most significant incidents in their lives to articulate self perception, these women dispel the myth that Dalit women are hapless victims. Struggling to overcome deprivation, discrimination and abuse, they express agency in verbalizing a desire for action. But what emerges as a characteristic in these narratives is a 'self in flux' marked by doubt, confusion and a gap between the self s image of itself and its perception by society (Bhave, 1988). The objective of this paper is to study the dialectics between the 'self and the 'community' in these narratives, to elucidate Dalit women's multifaceted and contradictory self-perception, implicated within the inter-dependencies of the community, with caste and gender as contextual co-ordinates.
\end{abstract}

Keywords: caste and gender, self and community, Dalit feminism, self-perception, Dalit women, Human Rights

\section{Introduction}

Much recent scholarship about the representation of Dalit women is based upon the premise of 'difference', vis-à-vis upper caste women on one hand and Dalit men on the other. It prominently projects them as a monolithic image which is essentialized and static. Frequently labeled as 'thrice marginalized' and 'doubly oppressed', these women are invariably homogenized as mute victims caught in rigid systems of kinship and patriarchy. Moving beyond the discussion of depraved sub-human existential conditions of Dalits, which is often the thrust of argument in the interpretation of autobiographies from a sociological perspective, my attempt in this paper, is to

\footnotetext{
(C) AesthetixMS 2019. This Open Access article is published under a Creative Commons Attribution Non-Commercial 4.0 International License (http://creativecommons.org/licenses/by-nc/4.o/), which permits non-commercial re-use, distribution, and reproduction in any medium, provided the original work is properly cited. For citation use the DOI. For commercial re-use, please contact editor@rupkatha.com.
} 
articulate how the texts challenge the communitarian control of the self by foregrounding the gendered experience of Dalitness.

Laura R. Brueck in the Introduction to her book Writing Resistance: The Rhetorical Imagination of Hindi Dalit Literature (2017), points out that "there has been scant attention paid to the ways in which Dalit writers consciously stylize their narrative form to construct social and political meaning" (p. 6). Thus, treating these texts as unmediated documents of singularly "authentic" experience is immensely problematic. Such a conclusive or simplistic framework is further complicated by the overlapping realities of class, gender and geography according to her. Dalit narratives are frequently posited as testimonios communicating authentic description of a life of dehumanization, discrimination, exploitation and starvation. Treated as 'repositories of subaltern truths' their interpretation is mostly linked to developmental needs with sociological and activist import, leading to glossing over of the stylistic aesthetics and formalistic analysis (Brueck, 2017). In the Afterword to the book, Baby Kamble's The Prisons We Broke (2008), Gopal Guru voices objection to the use of word testimonios, if interpreted following legal connotations, as the substitute term for Dalit personal narratives on two grounds. First, as a mode of representation it puts the responsibility to provide an evidence for proving innocence on the narrator as casualty, relegating it to pleading mode. Second, such a stance repudiates the possibility to interrogate the judge by elevating it to a privileged position (p. 159). However, he defends the use of the term as a moral medium of protest against adversaries both from within and without the category, by involving the "conception of the narrative self" (p.16o). He suggests that this self is collective as it is concomitant upon the community and is partly constituted by the life-story. M.S.S. Pandian opines about this textual strategy that, "[t]o name is to exercise power. But refusal to name can enable a politics of collectivity. In this case shroud of anonymity frees events, persons and institutions from the possibility of individuation and renders them as general. Anonymity thus becomes a mode of invoking larger solidarities" (2003, p.132). But since the claim to speak for others, elides difference under assumed representativity, what are the implications of this viewpoint upon the constituency of Dalit women, who remain silenced and marginalized within a community which is predominantly patriarchal with the politicallyawakened collective voice dominated by male authors? Does it not in a way foreclose the question of agency for Dalit woman as a subject, since historically she has not been allowed to instate herself? What role does gender play in the dialectic between 'I' and 'we' in the evolution of political consciousness, the process of emancipation and construction of self-hood? These are some of the questions that my paper intends to explore. In other words, the relationship between 'I' and 'we', depicted in the autobiographical narratives is neither direct nor unproblematic when read through the interface of caste and gender. To corroborate this, I refer to Sidonie Smith in $A$ Poetics of Women's Autobiography: Marginality and the Fictions of Self-representation (1987), as the constraints and emancipatory aspects of autobiographical storytelling with respect to engagement with androcentric generic expectations and cultural fictions have already been addressed by her. She points out that:

...the autobiographer's identity as a woman within the symbolic order of patriarchy affects her relationship to generic possibilities, to the autobiographical impulse, to the structuring of content, to the reading and the writing of the self to the authority of the voice and to the situating of narrative perspective, to the problematic nature of representation itself. (p.17)

Collected by a team headed by Sumitra Bhave under the auspices of Ishvani Kendra Pune, the book documents the results of a research, the objective of which was to elicit response from these women on the major incidents in their lives to cull out their self-perception. The four key 
thematic concerns which were fundamental to the dialogic interviews were - family, work, society and religion. The researchers have tried not only to retain the idiom, style and expression as presented to them, but also to treat the information gathered not as objective truth, rather true as far as these women's perception of it. Regarding the veracity of these accounts, Bhave in the Introduction to the book comments that, "a purely subjective experience is no less valid (for the entity involved in it) on the grounds of it being outside the purview of objective examinations" and for this reason, even when the experiences of these women seemed incongruous with their background or milieu, exaggerated or self-contradictory, they were not editorially discarded or disbelieved (1988, p. XLI).

\section{Victims or Agents?}

While presenting a succinct analysis of the personal narratives, Bhave points out that these women were so beset by the struggles of survival, that they never had the leisure to evaluate their actions. They had never tried to retrospectively scrutinize the events in their lives prior to this. Though not a representative sample of the whole category of Dalit women, the group comprised selected respondents of various age groups, who had been attending developmental programs being run in the community centre by a welfare organization and had shown willingness to communicate with the researchers. They understood the purpose of study and had consented to be a part of it. In the course of conversations, not only did they demonstrate a capacity to reevaluate certain significant decisions taken by them but could also causally relate the impact of such actions to their marginally improved conditions. For instance, Leela and Sangeeta, both desired their children to be educated and self reliant. Moreover, while Leela hoped to start a small scale industry for the women of the community, Sangeeta was actively involved in the political wing working on various projects. These women felt a sense of power in consciously re-calling and retelling their experiences (Bhave, 1988). By voluntarily choosing to participate in the construction of one's socially acknowledged identity, these women attempt what Margo Perkins has called 'rewriting the self, thereby not only overcoming marginalization by the dominant culture that renders them voiceless by originally defining and continually policing the narrative authority, but also undertaking a renegotiation of power relations by claiming the right to define oneself. What is striking to note is the instance that Ashoka, surprised the researchers by conversing unselfconsciously in English to narrate her life story, and gladly acknowledged that "she had been wanting to tell all about her life to some understanding person, for many days now, and the inability to do so had been preying on her mind" (Bhave, 1988, p.122). This remark highlights the fact that narratives are dialogically produced within a discursive context and never simply told, but told to someone. It is also indicative of the fact that 'silence' so often attributed to the subaltern women, is in many cases not their own silence, so much as the silence of institutionalized scholarship about them. Moreover, considering this remark within the purview of a simplistic understanding of agency as the capacity to make choices according to one's will, to conclusively and deterministically call Ashoka a fully agentive subject, would be problematic. As synoptically explained by Nivedita Menon in Seeing Like a Feminist (2012):

When are women to be considered as victims needing protection and when as active agents engaging with power and carving out their own spaces? The notion of 'choice' is not enough to answer this question - that if people choose to do something, it reflects their agency. It is because 'freedom of choice' is always exercised within strict boundaries that are nonnegotiable - these boundaries are defined by economic class, by race and caste and of course gender. (p. 175) 
To substantiate this let us take up Ashoka's case. Having moved to the city with her family right after her birth, she boasts of studying in an English Language School and could even complete graduation. It is not difficult to see that for Ashoka having a graduate degree, being fluent in English and even having the freedom to choose her husband, did not necessarily translate into 'empowerment'. Despite a love marriage, she couldn't experience the pleasure of egalitarian companionship that she had hoped for. She narrates:

My husband is now rude to me, insults me and does not say one kind word to me. I had to leave post-graduation half way through. My mother-in-law looked after baby in the day time, while I was at college, but the moment I was back, I had to do all the cooking and cleaning and washing and shopping and looking after the baby. ... Today I have to be at the beck and call of my husband. He couldn't care less if I were drawing my last breath. He wouldn't get himself a glass of water or close the window. ... My father says he had warned me before this. ... He also says that he had given me the freedom to choose my man myself and since I did, I have no room for complaint.... If I had my husband's cooperation I'd soon find a highly paying job. But he feels small before me because he is less educated, because no matter how hard he tries, he cannot speak English fluently. (p.130)

What placed limits on Ashoka's ambitions was the sexual division of labour according to which arduous housework is necessarily considered women's work. This supposedly primary responsibility significantly limits the horizon of opportunities for women across the spectrum of caste while making a choice - be it career or participation in politics. Moreover, women often indulge in self-limiting actions and beliefs in order to gain validation from the community. As Ashoka states, "My in-laws are forever telling me what is the 'ideal' - a wife must put up with all the injustices and injuries her husband heaps on her, a woman must not want to go out and laugh and be happy, a woman must not work at job" (Bhave, 1988, p. 148). Ashoka shows awareness of the fact that it is her caste/clan/ neighborhood/community that imposes innumerable restrictions upon the women. Instead of supporting them it rigidly scrutinizes their actions, ostracizing them if they steps out of line. What Ashoka articulates here is what Pierre Bordieu has called the 'habitus' of Dalit community - the unconsciously reproduced socialized perceptions and tendencies, embodied in persons as "lasting dispositions or trained capacities, structured propensities to think, feel and act in determinant ways which then guide them", revealing the interplay of agency and structure and how power in the community is culturally and symbolically created and re-legitimized (1984, p. 170). In cognizing her self-perception, she identifies the beliefs and assumptions practiced in her community to give a reflexive account of her disadvantaged location, explaining the causes of social asymmetries. She then exhibits agency suggesting a solution to this predicament that, "[i]t must be generally understood and accepted in an ideal community that a woman is not a subordinate or a toy or a useful machine; She too has a body that tires, a heart, a mind, her own desires. There must be an awareness of her as a person" (Bhave, 1988, p. 150).

\section{Re-scripting Rape, Domestic/Sexual Violence}

Much has been written about the appropriation of Dalit women by upper caste men through rape as a weapon of reprisal to emasculate the Dalit community. Anupama Rao, in Caste and Gender aptly remarks, "the bodies of Dalit women are seen collectively as mute, and capable of bearing penetration and other modes of making upper caste hegemony without the intervention of a discourse of desire and/or sexuality because of over-determination of this violence as casteprivilege" (as cited in Brueck, 2017, p. 156). Inadvertently, this has led to the reification of the 
social script of rape in literary accounts too, in which women are reduced to pawns in a social struggle between men. Brueck (2017) provides pertinent analysis of narratives of sexual violence in the literary context of Hindi Dalit creative and testimonial accounts. According to her, in the typically Dalit male-authored text, a woman is raped or brutalized very often in a public place. The narrative trope of rape is mostly placed in the very beginning of the story and this traumatic experience acts as a catalyst for the male protagonist sparking requisite political awakening. The trope gradually becomes tangential to the narrative as the focus turns to the male agent's recuperation of honour. Dalit women are thus reduced to mute spectacles, denied the identity of either a victim whose testimony validates her experience or an agent of her own self-preservation and retribution. This problematic has found partial redress in Kusum Meghwal's feminist rendering of the rape script and exploration of alternative possibilities for female agency, yet such agency is mostly cast in the form of a woman-centered rape revenge fantasy. In my opinion, the increased dissemination and public consumption of atrocity stories is symptomatic of commodification of such narratives. Moreover, little assessment has been made of atrocious domestic/sexual violence in Dalit homes. Most of the women respondents in Pan on Fire recall with dread their first sexual encounter with their husbands. Self control or self denial is alien to these men as untamable sexual urge is considered to be a proof of manliness; hence marital rape is rampant as men feel entitled to women's bodies. Their conduct is marked by unnecessary aggressiveness and toxic masculinity based on misogyny, resulting in frequent verbal, physical and sexual assault on their wives. Alcohol abuse and extramarital affairs are also pervasive in the community and act as contributing factors to the systemic culture of violence which has become normalized. Rukmini recalls, "At times I can hardly get up in the morning. My stomach hurts and back hurts and arms and legs. He has beaten me so much, twisted my arms so badly that I needed an operation to straighten them out" (Bhave, 1988, p. 90).

D. Sujatha (2014) has pointed out that domestic violence against Dalit women has received scant attention from social science researchers as it is treated as an insignificant issue compared to the violence they face in public places perpetrated by the dominant castes (stripping, parading naked, rape, atrocities, lynching and murder). Though established writers such as Bama (Tamil), Baby Kamble (Marathi) and Urmila Pawar (Marathi) have represented the privations of Dalit women faced in the domestic sphere, what remains obfuscated still in the literary analysis, is how these women continue to reinforce structures of their own oppression due to certain interpellated ideological constructs. Rakhma on being asked about her idea of a great woman reveals that, "Seeta and Savitri and all those - were great but no one becomes great by sitting around at home. You have to work hard and bear burdens and sorrows before you become great" (Bhave,1988, p. 63). Accustomed to backbreaking domestic labour, Sangeeta sees merit in rigorous self-depleting work. She narrates, "I keep on working even if I am sick. I work until I drop and take to bed! But he can't work at all. If I am away, he won't cook for himself, just eat rubbish brought from outside, so I don't usually go away - even to my mother's. All my sisters-in-law, all praise me for my hardworking nature, my neatness, my getting along with everyone. And I like it that they all praise me" (Bhave,1988, p. 19). In this context, let us consider the value of fidelity to one's husband undertaken with fervor and sanctity of religious observance. Uma Chakravarti, in Gendering Caste: Through a Feminist Lens (2003), gives a systematic exposition of the interface between caste and gender, locating it within the discourse of female sexuality. She purports that, at the ideological level women are made to internalize stridharma or pativratadharma through stereotypes like Sita and Savitri, making them control their sexuality and believe that they gain validation and respect by enduring suffering through quiet resilience. Chakravarti regards this as an ideological 'purdah' and calls it "a masterstroke of genius of the Hindu normative order" since 
it enables "iniquitous and hierarchical structures" to be "reproduced with the complicity of women" and complete masking of their subordination (pp. 72-74). Thus, we see that there is no simple top-down model of oppression; rather both the oppressor and the oppressed are acculturated into their roles. These women do verbalize discontent with the community's insistence on duty of wifely fidelity, chastity and placing premium on notions of 'honour' and 'obedience', yet they are unable to completely defy the norms. Their subjectivity is thus marked by fluidity and is in the process of continuous reformulation, afflicted by strife with the structures to which they are emotionally and psychologically bound. For instance, Savitribai says, "a woman really must keep on the right path. No matter what her husband does, she has to be loyal to him" (Bhave,1988, p. 161). Savitribai continued to put up with her husband's violent and indifferent behaviour despite his assaults, debauchery, numerous extramarital affairs and callous disregard for the welfare of his family. Yet contradictorily, she has definite ideas on husband-wife relationship. She refuses to remain subservient to her husband and demands that he should be deserving of the care which she is expected to provide him as a wife.

I'll feed myself and the children but won't lift a finger for him . . . . Among us Buddhists, you know you have to take oaths when you get married. The husband says, "I'll treat my wife right" and the wife says, "I'll serve my husband". I've been always true to my oath. I tell my husband that he took the oath in Ambedkar's name and it is immoral and wrong in him to go back on it like this. This is the curse of our community. No more than a quarter keep these oaths. The others are just like my husband, beat up the wife, drink, keep women. (Bhave,1988, p. 159)

Rather than the upper caste men or Dalit men, the chief agent of oppression for these women, as reflected in their accounts, is their vindictive and tyrannical mother-in-law. In spite of having suffered endlessly at the hands of the in-laws, Dalit women after becoming mothers-in-law themselves show little compassion toward their daughters-in-law. Furthermore, they often resort to perpetrating unbearable torment upon the latter and maintain authoritative control over their sons to consolidate their power. The reason for such behaviour, as enunciated by Nivedita Menon is that, under a patrifocal virilocal household, women derive their power and prestige solely from their relationship with men - their husbands and their sons who eventually become some other woman's husband. Thus, in such a structure within the domestic space where women wield limited influence, power struggles are inbuilt. They are inevitable because increased power for one implies decreased influence for another, making women their own worst enemies (p. 44).

In the light of above arguments, the self perception of these Dalit women, vis-à-vis, the two roles of wife and daughter-in-law, is often despairingly cast as a tortured prisoner struggling against asphyxiating constrictions. Commenting on the splintered nature of the constituency of Dalit women ridden with internal strife, Sumitra Bhave makes the following observation to suggest the reason for failure of women to come together under one banner to strive toward common goals:

The aggressive wing of the feminist movement often denies the compensatory satisfaction women derive through practicing the virtues of service and self- sacrifice and the traditionalists tend to deny women a life independent of the traditional roles she is expected to play. However, when one gets down to the individual one often finds that she wants both. ... Outwardly she seems to be a victim of injustice and double standards. But through manipulative politics she gets compensatory rewards both at familial and societal level. Since both these images- the downtrodden one as well as the Machiavellian, statesman like one- form a part of her self-image, latter has always undermined the anger of 
the former, preventing its explosion into a coherent revolution. Mutually exclusive social institutions coexist, interact and borrow from one another in the context of Indian culture. This is seen in operation in seemingly patrilineal society which at the same time reveres motherhood to an excessive degree. It is this reverence which allows a woman in fact to assume control of her household, though in institutional norm she remains powerless. (p. XLI-XLV)

\section{Migration and Modernity}

Debjani Ganguly in Caste and Dalit Lifeworlds : Postcolonial Perspective (2005), attempts a postcolonial reading of caste and calls Ambedkar, "modernity's interlocutor" for Dalits (p. 130). By referring to Ambedkar's key role in drafting the Constitution of India, and his training in the social sciences, law and economics at Columbia and the London school of Economics, she points out that his analysis of caste was constructed within the discursive structure/horizon of Orientalism, as reflected in his engagement with colonial modernity and Indian nationalism. He envisioned India as a democratic republic and as a result of his tutelage under John Dewey in Columbia, endorsed the objectivity and empiricism of social sciences (p. 142). She remarks that we can ascertain "[f]rom our retrospective theoretical advantage over him-he had no postfoundationalist philosophers to fall back on" and though he did make caste and untouchability the key problematic of Indian society, seeing purity/pollution axis as its cornerstone, yet he primarily read these categories through the idiom of power (p. 61). Gopal Guru (2004) has pointed out that while Gandhi necessitated the preservation of the idealized village, Ambedkar encouraged Dalits to migrate to cities to escape feudal backwardness and gain representation in India's progress toward modern nationhood. The meaning of modernity thus prominently got couched in the language of rights to equality, freedom and dignity, self-respect and recognition. Dalit intellectuals, ideologues and writers continue to treat theoretical paradigms advocated by Ambedkar, as the wellspring for their revolutionary ideals. We see the tropes of 'nation,' 'citizenship,' 'equality,' 'democracy' and 'rights' continue to configure the narratives of caste in present times, but due to the inequitable distribution of material wealth, the access to the modern has been limited to the upper classes whereas Dalits continue to be marginalized. Demystifying the fiction of the 'general category' used as a euphemism for uppercaste candidates, Satish Deshpande (2014) reveals how the term disguises in its anonymity a severely unequal access to privilege, since "[h]aving encashed its traditional caste-capital and converted it into modern forms of capital like property, higher educational credentials and stronghold in lucrative professions, this section believes itself to be 'caste-less' today" (p. 402). Evidently, caste discrimination in the traditional sense is disappearing, while there has been a resurgence of caste on the political front, reconfigured into the rhetoric of 'national interest' and 'merit' by the anti-reservationists, who represent themselves as 'secular' and 'modern citizens' and label those who publically invoke caste by asking for caste-based reservations as casteist. Thus, we see the promise of the city as a site of entry into the modern disproved, as a significantly large population of urban Dalits is still concentrated in slums, doing menial jobs struggling for daily survival.

Most of the women respondents recall that they came to the city following their fathers or husbands who came there in search of work. These men do not perform their traditional jobs now, yet their connect with the village has not been completely severed. The accounts presented by these women defy the 'metanarrative' projected in most autobiographical literary accounts that have been canonized as Dalit literature and is marked by certain normative spatial shifts 
including the following tropes - beginning in the village, childhood in Dalit basti, discrimination faced at the village school, move to college in a nearby town, finding redress in education and relocation from the village to the city, indicating a symbolic break from the traditional feudal village/caste hierarchy. In comparison to this, the narrations collated in this book appear incoherent and inconsistent, at times interrupted by long stories about distant relatives probably told by these women to avoid speaking directly about themselves. Peculiarly, these women display far more confidence while speaking about religion or society than they do while speaking about self and family. Vociferously critical of the hypocritical religious practices and superstitions pervasive in the community, these women denounce the double standards, staying true to the pro-modernity ideology propagated by Phule and Ambedkar with respect to showing enthusiasm towards education and political participation. They have realized that in a parliamentary democracy, their individual votes are as important as those of men; they are needed to swell the numbers during a morcha through which the government can be coerced into submitting to their demands. Yet not much has changed for them at the domestic front, except increased rigorous labour as Dalit men refuse to give up their male privileges. Moreover, these men squander their incomes on themselves or indulging in alcohol. Thus, despite being the bread winners, spending their entire earning on childcare and fulfilling the demands of the family, these women are still relegated to the subordinate/subservient position in the domestic realm and have no or limited decision-making rights. For instance, consider this excerpt from Chhaya's account: "I now really regret dropping out of school. I said to [my uncle] the other day I want to go back to school, and he told me that there's democracy in our family, my brothers are now grown up and they should all decide whether to send me to school or not" (Bhave, 1988, p.27). Ironically, Chhaya says this to express conviction in the justness of her uncle's decision, as she is very fond of him. But what is striking to note, is that 'democracy' is not gender-neutral or egalitarian when interpreted from the Dalit feminist standpoint. Democracy in a Dalit basti seems to be a male privilege, of which women are mere supplicants.

\section{Dalit Rights are Human Rights}

D. Sujatha (2014) makes certain relevant observations in the context of infringement of fundamental rights of Dalit women. According to her, a culture of violence that permeates Dalit community exacerbates the denial of fundamental right to life and security of life (Article 21) and non-discrimination on the basis of caste and gender (Article 15(1)) to these women despite constitutional guarantee. She remarks that "if rights are the legitimation of human needs, then the needs of Dalit women for personal security, socio-economic development and social justice are priority areas for intervention". In the Foreword to the National Human Rights Commission's "Report on Prevention of Atrocities against Scheduled Castes" made by K.B. Saxena released in 2002, Justice A.S. Anand, the chairperson of NHRC then, had advocated the adoption of a rightsbased approach and not a welfare-based one for defending the human rights of vulnerable and aggrieved sections of society. Since the late 1990s, even Dalit activists in order to mobilize international pressure for leveraging change towards Dalit cause have reworded their grievances in internationally recognizable terminology of work-and-descent-based discrimination and started calling caste discrimination India's 'hidden apartheid' adopting the rhetoric of Human Rights. Clifford Bob in his article, "Dalit Rights are Human Rights: Caste Discrimination, International Activism, and the Construction of a New Human Rights Issue" (2007) makes nuanced analysis of this phenomenon, chronicling a lengthy period of neglect towards Dalit issues as well as the recent slight but significant success in grabbing attention in international 
arenas including various United Nations organs, International Human Rights NGOs, which facilitated the formation of a Transnational Advocacy Network (TAN) around domestic Indian activists and select governments, especially in Europe, which began pressuring India for action after the start of the $21^{\text {st }}$ century (p.17o). Rebecca Adami (2014) enunciates the flip side of dominance of legal discourse in Human Rights Education on political agency and states that:

"[t]he initial juridical significance of human rights focuses on rights as legal entitlements where the urgency for human rights emerges primarily in human rights violations. . . Making human rights 'active' in a legal sense is a process very much dependent on national legislative measures. One could say that the enforcer of human rights in this sense are the lawyers, judges, and legal laymen working in a legal system, and diplomats, governments, and international politicians who negotiate amendments and reservations to the texts. (p.165)

So the hazard of adopting this approach in seeking development for marginalized sections is that it necessitates the categories of 'HR agent' and 'victim', entailing representation by experts and lawyers as intermediaries who translate the vocabulary of legal framework to aggrieved individuals/communities lacking such legal competence or recourse to legal aid, thereby severely jeopardizing their 'own political voice'. Adami builds on Hannah Arendt's notion of political space with respect to human rights, by amalgamating Adriana Cavarero's radical rethinking of politics in terms of 'voice' and 'uniqueness' as well as the conceptualization of 'absolute local space', "which is not a geographical territory, but created whenever and wherever polemical voices are raised in concert" by collapsing the dichotomies of public/private to locate political agency in the "in-between of unique persons who through their personal voice speak out against injustice and oppression, not bound by identity politics but a willingness to act in the world" (p.177). It is a deterritorized space where diversity and uniqueness are voiced through narratives allowing reciprocal communication of voices in pluralistic relationality. Since personal narratives have already been used world over to further Human Rights claims, envisioning Dalit personal narratives as 'absolute local space' and shifting focus to uniqueness of voice embodied in the text instead of an essentialized identity classification, can enable the elucidation of complexity of a dynamic subject not confined to the categories of 'victim' or 'agent'. This also keeps into purview, the fact that identification is a contingent process over-determined by material conditions, symbolic resources and embedded in discourses. (Hall, 2ooo p.16) This approach facilitates actualization of Sharmila Rege's Dalit feminist standpoint which envisions Dalit women's subjectivity as multiple, heterogeneous even contradictory (2014, p. 342). Rege in her essay "Dalit Women Talk Differently: A Critique of 'Difference' and Towards a Dalit Feminist Standpoint Position" (2014) presses for "transforming difference into standpoint" in order to articulate the interface among different hierarchies of class, caste and gender. To her, focus on difference leads to narrow identitarian politics and ghettoisation. Transforming it into an epistemological standpoint, will not only enable liberatory interrogations of the middle class biases of the earlier feminist standpoint, but also enable re-conceptualization of the discourse of sexual politics from individual narratives to collective contestations of intractably intermeshed hierarchies/ asymmetries of Brahmanical social order, caste based division of labour and sexual divisions of labour (pp. 335-343).

In my opinion, Pan on Fire, as a text provides substantive insights into the construction of the 'selfhood' of Dalit women located in urban slums from a Dalit feminist standpoint. As 'absolute local space', it documents unique personal narratives by Dalit women, not only vizibilizing hitherto obfuscated Human Rights violation issues within the domestic realm, thereby 
instating their political voice in terms of a dynamic and evolving subjectivity, but also further registers the potentiality of solidarity through relational associations of individuals based on willingness to act and setting up a more accommodating modality for Dalit mobilization to incorporate disparate perspectives.

\section{Conclusion}

To sum up the arguments in Bhave's words,

...their newly woken sense of political power, their guilt and doubt regarding the religion, their desire for middle class standards of living, their present poverty, their awareness of lack of education and ignorance arising therefrom, the necessity of earning their bread forced upon them by their irresponsible and absconding men have produced a jumble of contrasting ideas making these women's self-image into a patchwork quilt. (1988, p. XXXVIII)

In the light of the explication made before, it can be ascertained that, what emerges in the text under study, is a multi-layered self-perception by Dalit women, that has: a non-brahmanical core evident in the norms pertaining productive and domestic labour, with an overlay of brahmanical ideology implied by premium on notions of pativrata, chastity, obedience and a top layer comprising modern discourse conspicuous in an attempt to negotiate space for self-fashioning. An ambiguous, yet symbiotic relationship between the hegemonic and the subaltern within the psyche of the subject is glimpsed, who tries to negotiate with the subconscious conditioning of primary socialization to improve its conditions.

Not limited to this, it offers an entry point into the textuality of Dalit culture, both material and discursive, enabling discovery of underlying processes whereby norms detrimental to the well-being of these women are established and maintained. We see the fallacy of homogenizing the identity of Dalit women into a monolithic image of a passive victim as well as the sophism of glorification of productive culture of Dalit families as egalitarian, which was projected in the post-Ambedkar phase of Dalit movement as part of identity politics. It also elucidates how reading Dalit autobiographical/personal narratives, as both socio-biographies hinged on identity politics as well as 'testimonies' based on legalistic connotations, is deeply problematic.

Extrapolation of these observations can enable revisionary contrapuntal readings of autobiographical literary representations of Dalit women in canonized Dalit texts. Sociobiographies can be deconstructed to reveal the negative implications of privileging the communitarian perspective which is decidedly masculine and patriarchal. It would also enable apprehension of conflict between tradition and modernity within the emerging Dalit consciousness, as embodied by a protean subjectivity grappling with cultural categories that discursively construct, condition and discipline its individuality, rather than understanding Dalit woman's identity as an essentialized entity with respect to powerlessness and subordination.

\section{References}

Adami, Rebecca. (2014). Human rights for more than one voice: rethinking political space beyond the global/local divide, Ethics \& Global Politics, 7(4), 163-18o.

Bhave, Sumitra. (1988).Pan on fire: Eight dalit women tell their story. New Delhi: Indian Social Institute. 
Bordieu, P. (1984).Distinction: A social critique of judgment of taste. London: Routledge.

Bob, Cliford. (2007). Dalit rights are human rights: caste discrimination, international activism, and the construction of a new human rights issue. Human Rights Quarterly 49(1). Project Muse, 167-193.

Brueck, Laura R. (2017).Writing resistance: The rhetorical imagination of Hindi dalit literature. India: Primus Books.

Chakravarti, Uma. (2003).Gendering caste: Through a feminist lens. Calcutta: Stree.

D, Sujatha.(2014). Redefining domestic violence: experience of Dalit women.EPW. 49(47), 19-22.

Deshpande,Satish. (2014).Caste and castelessness: Towards a biography of the 'general category'. In Satish Deshpande (Ed.).The problem of caste.(pp.402-410). New Delhi: Orient Blackswan Pvt. Ltd.

Ganguly, Debjani. (2005).Caste and dalit lifeworlds: Postcolonial perspectives.New Delhi: Orient Blackswan Private Limited.

Geeta, V. (2009). Bereft of being: The humiliation of untouchability. In Gopal Guru (Ed.) Humiliation.(pp.93-107) New Delhi: Oxford University Press.

Gopal, Guru. (2008). Afterword. In Baby Kamble. The prisons we broke. (Maya Pandit. Trans.). Hyderabad: Orient Longman.

Gopal Guru. (2000). Dalits in pursuit of modernity. In Romila Thapar (Ed.) India: Another millenium?.(pp.123-137).New Delhi: Viking Penguin.

Hall, Stuart. (200o).Who needs 'identity' ?. In Gay, Paul du and Jessica Evans (Eds.) Identity: a reader, (pp. 15-30). London: Sage Publications.

Menon, Nevidita. (2002). Seeing like a feminist. Gurgaon: Zubaan-Penguin Books.

Navarro, Z. (2006) In Search of Cultural interpretation of Power, IDS Bulletin,37(6),11-22.

Pandian, M. S. S. (2003). On a Dalit woman's testimonio. In Anupama Rao (Ed.) Gender and caste.(pp.129135). New Delhi: Kali for Woman.

Perkins, M. (2000).Autobiography as activism: three black women of the sixties. Jackson: University Press. Mississippi.

Rege, Sharmila.(2014). Dalit women talk differently: A critique of 'difference' and towards a

Dalit feminist standpoint position." In Satish Deshpande (Ed.) The problem of caste : readings on the economy, polity and society.(335-343) New Delhi: Orient Blackswan Private Ltd.

Smith, Sidonie. (1987).A poetics of women's autobiography: Marginality and the fictions of selfrepresentation. Bloomington: Indiana University Press.

Saxena, K.B. (2002) Report on prevention of atrocities against scheduled castes. New Delhi: National Human Rights Commission.

Fernando, Franco. Macwan. Jyotsna, \& Ramanathan. Suguna. (2000). The silken swing: The cultural universe of dalit women. Calcutta: Stree. 